\title{
The Source of Shocks and the Role of Exchange Rate as a Shock Absorber: A Comparative Study in the Crisis-hit East-Asian Countries
}

\author{
Siok Kun Sek \\ Economics Department, Christian Albrechts University of Kiel \\ Olshausenstr, 66A-007, 24118 Kiel, Germany
}

Tel: 49-431-888-6969 E-mail: siokksek@bwl.uni-kiel.de

\begin{abstract}
Focusing on several crisis-hit East-Asian countries, this paper seeks to uncover the main source of shocks and its link to the performance of policy regime in these countries between the two sub-periods of pre- and post-crisis. A comparative structural VAR analysis is conducted to study the dynamic of shocks. The results show that the economies of East-Asian countries are mainly driven by domestic shocks and shocks are asymmetric. External shocks have low effects on domestic variables but they are increasing over time. Given that real exchange rate reacts stronger to real economy but lower to its own shock, and that the economies tend to experience real depreciation and lower volatility in inflation in the post-crisis period, the results imply more effective policy and greater role of exchange rate to act as a shock absorber under floating exchange rate regimes aftermath the crisis.
\end{abstract}

Keywords: Exchange rate, Inflation targeting, Asymmetric shocks

\section{Introduction}

The understanding in the business cycle fluctuations and the economic structures are of emphasized as they provides us the information on the source and the transmission mechanism of shocks which are important in the design of effective monetary policy and also for the evaluations of policy regimes. The nature of shocks or the source of business cycle fluctuations is closely linked to the policy regimes. Economic theory tells us that floating regimes are more feasible in the presence of large external or real shocks as these regimes provide less costly adjustments through relative prices in dealing with such shocks. On the other hand, fixed regimes are preferred under more prominent domestic or nominal shocks (Cavoli \& Rajan, 2003). This implies that the nature of shocks is crucial in determining the performance of policy regimes. At the other end, policy regimes could be matter in determining the transmissions and influences of shocks (Desroches (2004) and Hoffmaister et al. (1997)).

Focusing on several crisis-hit East-Asian countries, a structural VAR model is applied to analyze the relative importance of various shocks on domestic economy and it has two main objectives. First, it seeks to reveal the main source of shocks in the business cycle fluctuations in these emerging countries. In particular, comparisons of the results are made across countries and over time (pre- and post-crisis periods). Second, this paper also seeks to investigate if exchange rate plays a more effective role as a shock absorber aftermath the crisis or after the change to the floating regimes in East-Asia.

The results indicate that the domestic economies of East-Asian countries are driven mainly by domestic shocks, in particular the supply or real shocks. External shocks only explain a relatively low fraction in the economic fluctuations of this region. However, there is a tendency of higher effects of external shocks on domestic economies in the post-crisis period. Besides, East-Asian countries are subject to asymmetric country specific shocks where the relative importance of shocks differs across countries and the economic variables in these countries react differently to external shocks. Exchange rate is a source of shocks to itself but it is declining in the post-crisis period. The disturbance of exchange rate shock does not transmit largely to the real economy and hence it is not harmful. However, floating exchange rate regimes permit higher volatility in exchange rate and hence greater effects of external shocks on domestic economy of East-Asia. These countries also experience lower volatility in inflation and depreciation in real exchange rate, indicating higher stability in inflation and greater role for exchange rate to act as a shock absorber under the floating regimes aftermath the crisis.

The remainder of the paper proceeds as follows. Section two reviews the changes in the policy regimes in several East- 
Asian countries followed by the empirical literature on the relationship between monetary policy and the nature of shocks. Section three discusses the methodology and Section four is about the data. Section five reports the results. Section six discusses the role of exchange rate as a shock absorber. Section seven concludes.

\section{Monetary policy framework in East-Asia}

The financial crisis of 1997-98 and the collapse of the pegged exchange rate system urged the monetary authorities in these countries to reconstruct the monetary policy frameworks and looked for better alternative implementable policy regimes. Drastic changes in the policy regimes are observed in which most of the crisis-hit East-Asian countries have moved from the rigid exchange rate regime to the flexible one and inflation targeting after the crisis of 1997-98 (see Table 1). According to the IMF classification, Korea has moved from managed floating to independently floating since November 1997 while Philippines remains the same independently floating regime. Thailand has moved from fixed regime to independently floating since July 1997. In contrast, Malaysia moved from managed floating to pegged system for the period from September 1998 to July 2005 and later shifted back to the managed floating regime. Besides, several countries have adopted the inflation targeting regime. The countries that have shifted to the inflation targeting regime include Indonesia, Korea, Philippines and Thailand. Korea was the first country in Asia that has adopted the inflation targeting regime, i.e. in April 1998, followed by Indonesia, in January, 2000, Thailand in May 2000 and later Philippines in January 2002.

The drastic change in the policy regimes in these crisis-hit emerging countries has induced many researches and debates regarding the merits and effectiveness of different policy rules and exchange rate regimes, in particular the role of exchange rate in the monetary policy framework for emerging countries aftermath the crisis. This paper takes a different approach to study the change in the structure of economy and the nature of shocks under two different policy regimes in the preand post-crisis in several East-Asian countries.

\subsection{The source of shocks and the performances of policy in East-Asia}

Empirical studies investigating the business cycle fluctuations and the structure of shocks in emerging countries are closely linked to the study in the topic of optimum currency area (OCA). These studies intend to investigate if the economic structure and the financial and politic aspects in several East-Asian countries fulfill the criteria to form the optimum currency area (OCA) in this region. The results support the formation of OCA if the business cycles or macroeconomics in these countries exhibit some similarities and shocks are symmetric. This paper has no intention to study the criteria of OCA for the region of Asia but it seeks to find the link between the structure and/ or the nature of shocks and the policy performances under different policy regimes in East-Asia. The following summarizes some empirical findings on the structure and the nature of shocks in East-Asia followed by the comparisons in the merits of policy regimes across countries.

Investigating the structural of shocks, most studies do not favor the formation of OCA for East-Asia as majority of these countries exhibit idiosyncratic and country specific shocks ((Chow \& Kim (2003), Zhang et al. (2004), Sun \& An (2008) and Hoffmaister \& Rolds (1997)). Besides, East-Asian countries are mainly driven by domestic supply shocks. External shocks only explain a small part of the economic fluctuation in these countries (for example Sun \& An (2008) and Hoffmaister \& Rolds (1997)). On the other hand, a number of studies find significant correlations of (domestic) shocks in this region and suggest the formation of OCA in a subset of East-Asian countries ((Kwan (1994), Eichengreen \& Bayoumi (1996), Bayoumi et al. (2000) and Zhang et al. (2004)). These studies find that although East-Asian countries differ in economic and financial conditions, the region is not far away from Europe in satisfying certain criteria of OCA. However, more pronounced differences are found in the degree of financial development and the lack of political commitment. Since the preconditions for the sustainable and durable regional arrangement are political criteria, the results do not favor the formation of OCA in Asia. On the other hand, Saucier (2002) finds two groups of Asian countries satisfy the factor mobility and trade criteria for OCA, i.e. Japan and Asian NIEs (Newly Industrialized Economies, i.e. Hong Kong, Korea, Singapore and Taiwan) and China and ASEAN4 (Indonesia, Malaysia, Philippines and Thailand). Focusing the analysis in five ASEAN countries from 1960 to 1996, Ramayandi (2005) finds that aggregate supply shock is not correlated in these countries. However, the results reveal significant correlation when the period of analysis is extended to 2002 . On the other hand, aggregate demand shock is correlated with relatively higher magnitude under both samples. He concludes that although ASEAN countries satisfy some preconditions of OCA, it may need a lot of process and longer time to realize the idea. Investigating the business cycle features in Asian and G7 countries, Kim, Kose \& Plummer (2000) find that Asian economies are more open in trade than that of G7 economies. At the same time, these economies show higher diversification in their export over time. The investment, export and import ratio to output increase significantly. However, the agricultural sector share is diminishing over time. The trade in total export within the Asian region has increased over time as well. The results also show that the main factors that drive the macroeconomic fluctuations in Asian countries are investment, government spending and consumption.

Apart from these results, some studies are interested to evaluate the merits of policy regimes following drastic shifts in exchange rate regimes in East-Asia after the Asia financial crisis of 1997-98 (for example Desroches (2004) and Edwards (2006)). Investigating the source of macroeconomic fluctuations in 22 emerging countries with different exchange rate 
regimes, Desroches (2004) demonstrates that exchange rate regime is a critical factor in determining the differences in the transmission mechanism of shocks across emerging countries. Using a sample of 38 developing countries, Hoffmann (2005) seeks to compare to what extent the exchange rate regimes matter in utilizing the role of exchange rate as a shock absorber. His results indicate that economies with floating exchange rate regimes tend to experience real exchange rate depreciation, hence more prominent role for the exchange rate to act as a shock absorber under floating regimes. Edwards \& Yeyati (2005) analyze the effect of terms of trade or real shocks on the economic performance under different policy regimes in 183 countries over 1974 to 2000. Their results reveal that flexible exchange rate regimes help to absorb real impact of shocks in emerging and industrial economies. Output also reacts stronger to negative shocks under a pegged exchange rate. Their results also support the view where regime flexibility is positively correlated with output growth. The empirical studies based on East-Asian countries are very limited. Most of the studies are based on the developed economies and European countries. These studies does not directly link the nature of shocks to the policy performances but to evaluate and compare the role of exchange rate as a shock absorber across countries (for example, Drine \& Rault (2004), Artis \& Ehrmann (2006) and Alexius \& Post (2008)).

\section{Methodology}

Most of the empirical studies on the small open economy framework apply structural vector autoregressive (SVAR) technique as this technique enables analysis on the transmission of shocks through impulse responses and variance decompositions. For simplicity, the domestic economy can be represented by the structural model:

$$
\begin{gathered}
A_{0} X_{t}=A_{1} X_{t-1}+\ldots+A_{q} X_{t-q}+B \varepsilon_{t} \\
X_{t}=\left[\begin{array}{lllllll}
\Delta y_{t}^{*} & \Delta i_{t}^{*} & \Delta p_{t}^{*} & \Delta y_{t}^{*} & \Delta r_{t} & \Delta p_{t}
\end{array}\right]
\end{gathered}
$$

where $A_{0}$ and $B$ are the $(K \times K)$ matrices which indicate instantaneous relationship relations of variables in $X_{t}$ and $\varepsilon_{t}$ respectively; $A_{t}$ 's are $(K \times K)$ coefficient matrices given $(\mathrm{i}=1, ., \mathrm{q})$ and $\varepsilon_{t}$ is the vector of structural shocks. There are six endogenous variables, i.e. foreign output/ supply $\left(y_{t}^{*}\right)$, foreign monetary policy $\left(i_{t}^{*}\right)$, foreign price/ demand $\left(p_{t}^{*}\right)$, domestic output/ supply $\left(y_{t}\right)$, real exchange rate $\left(r_{t}\right)$ and domestic demand $\left(p_{t}\right)$. All the variables are in first differenced log term. $\varepsilon_{t}$ consists of six shocks, i.e. foreign supply shocks, foreign policy shocks, foreign demand shocks, domestic supply shocks, real exchange rate shocks and domestic demand shocks. This structural form of equation can be transformed into reduced form by pre-multiplying both sides of variables with $A_{0}^{-1}$ (see Breitung et al. (2004)):

$$
X_{t}=\bar{A}_{1} X_{t-1}+\ldots+\bar{A}_{q} X_{t-q}+e_{t}
$$

where $\bar{A}_{j}=A_{0}^{-1} A_{j} ;(j=1, \ldots, q), e_{t}=A_{0}^{-1} B \varepsilon_{t}$ and $E\left[\varepsilon \varepsilon^{\prime}\right]=I$.

As in Favero, (2001), equation (1) can be written in a generic form as:

$$
\left[I_{K}-A(L)\right] X_{t}=B \varepsilon_{t}
$$

where $A(L)=\sum_{i=1}^{q} A_{i} L^{i}$ and $A_{0}=I_{K}$ in order to be invertible.

By inverting the term $\left[I_{K}-A(L)\right]$, we get the Wold moving average representation of structural form VAR process:

$$
\begin{gathered}
X_{t}=C(L) \varepsilon_{t} \\
X_{t}=C(L) \varepsilon_{t}=\Psi_{0} \varepsilon_{t}+\Psi_{1} \varepsilon_{t-1}+\ldots+\Psi_{s} \varepsilon_{t-s}
\end{gathered}
$$

where $C(L)=\left[I_{K}-A(L)\right]^{-1} B$ and $\Psi_{0}=B$

From equation (2), we know that $e_{t}=A_{0}^{-1} B \varepsilon_{t}=B \varepsilon$ given that $A_{0}$ is an identity matrix. Then, $\varepsilon_{t}=B^{-1} e_{t}$. Substitute this relationship into equation (4) gives:

$$
X_{t}=C(L) \varepsilon_{t}=C(L) B^{-1} e_{t}
$$

Equation (5) can be written in a Wold representation of the reduced form VAR process:

$$
X_{t}=\Phi_{0} e_{t}+\Phi_{1} e_{t-1}+\ldots+\Phi_{s} e_{t-s}
$$

where $\Phi_{i}=\Psi_{i} B^{-1}, \Phi_{0}=I_{K}$ and $i=0,1, \ldots$

\subsection{Forecast error variance decomposition and impulse response function}

The system equation of VAR applies two important tools in analyzing the dynamic effects of structural shocks, namely the forecast error variance decomposition (FEVD) and the (accumulated) impulse response function (IRF). The forecast error 
variance decomposition gives us the relative importance of shocks on determining the variation in domestic variables. This tool is constructed as the h-step forecast error from the structural innovations (Breitung et al. (2004)):

$$
X_{T+h}-X_{T+h \mid T}=C_{0} \varepsilon_{T+h}+C_{1} \varepsilon_{T+h-1}+\ldots+C_{h-1} \varepsilon_{T+1}
$$

Denoting the ij-th element of $\Psi_{n}$ as $\Psi_{i j, n}$, the k-th element of the forecast error vector can be written as:

$$
X_{k, T+h}-X_{k, T+h \mid T}=\sum_{n=0}^{h-1} \psi_{k K, n} \varepsilon_{K, T+h-n}
$$

Then, the forecast error variance is constructed as the following with the pre-condition that the structural disturbances are not serially correlated:

$$
\sigma_{k}^{2}(h)=\sum_{n=0}^{h-1}\left(\psi_{k 1, n}^{2}+\ldots+\psi_{k K, n}^{2}\right)=\sum_{j=1}^{K}\left(\psi_{k j, 0}^{2}+\ldots+\psi_{k j, h-1}^{2}\right)
$$

The term in bracket of (10) indicates the contribution of variable $\mathrm{j}$ to the forecast error variance of variable $\mathrm{k}$ for h-step horizon. The contribution in percentage can be obtained in the following way:

$$
\varpi_{k j}(h)=\left(\psi_{k j, 0}^{2}+\ldots+\psi_{k j, h-1}^{2} / \sigma_{k}^{2}(h)\right)
$$

Another tool that used to interpret the VAR model is the (accumulated) impulse response function. The (accumulated) impulse response function shows the (accumulated) responses of economic variables to a one percent increase in orthogonalized shocks at given time horizons. In order to get the orthogonalized shocks, i.e. when shocks are instantaneously uncorrelated, B is written in a lower triangular matrix such that the variance covariance matrix is $\sum_{e}=B B^{\prime}$. The orthogonalized shocks are captured by $\varepsilon_{t}=B^{-1} e_{t}$. The impulse responses to orthogonalized shocks may be obtained from equation (4) where $\Psi_{i}=\Phi_{i} B$ for $i=0,1,2, \ldots$ For the accumulated long-run effects of orthogonalized shocks, they are replaced by $C(1)=\Phi B$.

\subsection{Identification}

In order to identify the structural parameters, we need to impose restrictions on the parameter matrices either through contemporaneous restrictions on the parameter matrices of $A_{0}$ and $\mathrm{B}$ or long-run restrictions on the total effects of structural shocks. This paper applies the long-run restrictions method proposed by Blanchard \& Quah (1989). The long-run restrictions model sets $A_{0}$ as an identity matrix, i.e. $A_{0}=I_{K}$. The restrictions are based on the long-run restrictions that imposed on the cumulative impulse response function. Totally $K(K-1) / 2$ restrictions are imposed on the lower triangular matrix where some of the structural shocks do not have contemporaneous impacts on the other variables. The long-run impact matrix can be written in the following form:

$$
\begin{aligned}
& e_{t}=C(1) \varepsilon_{t} \\
& \left(\begin{array}{c}
e_{t}^{y *} \\
e_{t}^{i *} \\
e_{t}^{p *} \\
e_{t}^{y *} \\
e_{t}^{r *} \\
e_{t}^{p *}
\end{array}\right)=\left(\begin{array}{cccccc}
C(1)_{11} & 0 & 0 & 0 & 0 & 0 \\
C(1)_{21} & C(1)_{22} & 0 & 0 & 0 & 0 \\
C(1)_{31} & C(1)_{32} & C(1)_{33} & 0 & 0 & 0 \\
C(1)_{41} & C(1)_{42} & C(1)_{43} & C(1)_{44} & 0 & 0 \\
C(1)_{51} & C(1)_{52} & C(1)_{53} & C(1)_{54} & C(1)_{55} & 0 \\
C(1)_{61} & C(1)_{62} & C(1)_{63} & C(1)_{64} & C(1)_{65} & C(1)_{66}
\end{array}\right)\left(\begin{array}{c}
\varepsilon_{t}^{s *} \\
\varepsilon_{t}^{i *} \\
\varepsilon_{t}^{d *} \\
\varepsilon_{t}^{s} \\
\varepsilon_{t}^{r} \\
\varepsilon_{t}^{d}
\end{array}\right)
\end{aligned}
$$

where $\mathrm{C}(1)$ is the long-run matrix of $\mathrm{C}(\mathrm{L})$. As the long-run impact matrix is in lower triangular choleski decomposition, the ordering of the variables matters in determining the structure of the shocks. The first variable has impacts on all variables below it but it does not receive any impacts from these variables. The second variable only receives the impacts from the first variable. It does not have any impact on the first variable but it can influence all the variables below it. This rule applies to the all subsequent variables. The foreign variables are ordered before the domestic variables by assuming domestic economy is relatively small and has no impact on the foreign economy but receives the foreign shocks exogenously. The orderings among foreign and domestic variables are based on the standard macroeconomic theory as in Sun \& An (2008).

\section{Data}

The analysis is focused on the crisis-hit East-Asian countries. As most of these countries have shifted to more flexible exchange rate regimes following the financial crisis of 1997-98, it is of interest to investigate how the shift in the policy regimes is linked to the change in the structure and relative effect of shocks in these countries between the two subperiods. For the purpose of this study, the data is divided into two sub-samples, i.e. before 1997M7 (as pre-crisis period or period I) and from 1999M1 and afterwards (as post-crisis period or aftermath the shift of policy regimes or period II). The foreign country is represented by the US and the domestic country refers to individual East-Asian country. The industrial 
production index is used as the proxy for output variable (which is seasonally adjusted) as most of the East-Asian countries do not have long enough series for GDP. The monetary policy variable is proxied by the interest rate data. In the case of US interest rate, the Federal Fund Rate (FFR) is used to represent the monetary policy. The real exchange rate is defined as the relative price of non-traded goods (CPI) in terms of traded goods (PPI) as in Desroches (2004) and Hoffmaister \& Rolds (1997). This series is constructed as the ratio of domestic CPI over foreign PPI (in term of domestic currency, i.e. foreign PPI series multiplied by nominal exchange rate per USD series):

$$
r_{t}=\frac{C P I_{t}}{e r_{t} P P I_{t}^{*}}
$$

The increase in real exchange rate implies appreciation while the decline in it means depreciation. All the data are in monthly and are obtained from the International Financial Statistics (IFS), IMF. Due to the data availability problem, only four East-Asian countries are included in this study. These countries are Korea, Malaysia, Philippines and Thailand. The data span from 1981M1-2008M4 in the case of Korea and Malaysia. Philippines takes the range from 1985M1-2008M4 and Thailand 1987M1-2008M4.

\section{Results}

The structural VAR system equation is estimated using the data for the two sub-periods (the pre- and post-crisis periods) for each country. All the series are in logarithms (except the interest rate series) in order to capture the percentage change in the variables. Applying the unit-root test of Augmented Dicky-Fuller (ADF) to the two sub-periods sample shows that in most cases, these variables are not stationary in their levels but they are stationary in differenced terms (see Table 2). In order to generate efficient estimators, the system equation is estimated in differenced form (Note 1). The long-run relationship of variables is identified using the Blanchard \& Quah technique. Akaike Info Criterion, Final Prediction Error and Schwarz Criterion suggest different length of lags to be included in the analysis of each country. As in Bayoumi \& Eichengreen (1994), this paper includes the same length of lags (six lags) in the model for all countries in order to preserve symmetric of specifications (Note 2). The constant and seasonal dummies are assumed in each case. Impulse dummy is considered in case significant impulse or break of series is detected/suggested by the unit-root with structural break test (Note 3).

Before discussing the results, the data for each country are studied. As observed from the statistic for domestic variables (see Table 3), all the four countries in the analysis experience a decline in the change in price or inflation and growth rate in the post-crisis period (Note 4). The data reveal the trade-off between the output growth and the inflation. Although these countries have improved the inflation rate, they face the trade-off in the form of lower output growth. On the other hand, these countries are moving from appreciation in real exchange rate to depreciation (with the exception of Korea). As discussed later, the move from appreciation to depreciation indicates a positive outcome, i.e. exchange rate plays a more effectively role as shocks absorber (see section 5.2).

\subsection{Forecast error variance decompositions (FEVD)}

The forecast error variance decomposition shows the percentage relative explanatory power of each orthogonalized shock on the variation of each domestic variable. In line with the results reported in previous studies, the business cycle fluctuation (output) in East-Asia is driven by domestic shocks. External shocks explain a relatively low economic fluctuation in these countries. The results hold in the two sub-periods (see Table 4).

Comparing the results of FEVD across countries and over time, it is observed that the relative impact of external shocks is increasing while that of domestic shocks is declining (with the exception of Philippines's real exchange rate). The explanations for this phenomenon include higher trade openness of East-Asian countries, integration in international trades and the moved to more flexible exchange rate regimes which permit greater foreign effects on domestic economy. Previous studies show that the degree of economic integration and the shares of investment, exports and imports in Asia have increased significantly over the last three decades. These countries also exhibit higher degree of trade openness which explains the reason why they are more prone to external shocks (Kim, Kose \& Plummer (2003)).

The results also indicate that the main source to the output fluctuations is domestic supply or real shock while the main factors that contribute to changes in real exchange rate are domestic demand and real exchange rate shocks (nominal shocks). Domestic supply and demand shocks are the main determinants to the variation in domestic inflation.

\subsection{Impulse response function (IRF)}

The (accumulated) impulse response function shows the responses of each variable in the system equation to a positive one standard deviation of each shock. It provides us the information on the size of shocks and also the dynamic of shocks, i.e. how the shocks induce different reactions of economic variables over time.

Table 5 summarizes the results of accumulated IRF (in numerical values) for each domestic variable in response to each shock under the $1^{\text {st }}, 6^{\text {th }}, 12^{\text {th }}$ and $18^{\text {th }}$ month horizons of several East-Asian countries. Table 7 shows the figures of impulse response function of shocks to the change in real exchange rate. The negative sign for the change in output and price indicate the decline in both variables under a $1 \%$ increase of each shock while the negative sign in the response 
of the change in real change rate implies depreciation. The results show that the output growth and the change in real exchange rate are more sensitive to shocks in compare to the domestic inflation. Both variables are more volatile. The domestic output growth is mainly determined by the domestic supply shock. However, the size of domestic supply shock is declining but the size of external shocks is increasing in the period aftermath the crisis in East-Asia. The change in real exchange rate seems to be more volatile in period II in response to shocks. The increase in the volatility of real exchange rate reflects the abandon of fixed exchange rate regimes and the adoption of flexible exchange rate and inflation targeting regimes in most of the East-Asian countries aftermath the crisis. The shift in the policy regimes and the implementation of inflation targeting in several East-Asian countries aftermath the crisis also help to maintain the low and stable inflation rate. These changes are demonstrated in the results here where the response of inflation to shocks has declined in period II.

Besides experiencing different sizes and impacts of shocks, the economic variables in East-Asia also react differently to shocks between the two sub-periods. An increase in the foreign supply shock leads to the decline in the output growth in the pre-crisis period but it tends to increase the domestic output growth in the post-crisis period (see Table 5). The theoretical prediction is when there is an increase in the foreign supply such as the increase in the foreign productivity; the foreign price tends to be lower. Since domestic price is relatively higher than foreign price, this induces a rise in domestic interest rate and domestic currency appreciates. The opposite outcome is possible if the authority controls the movements in exchange rate. The public will revise the expectation on future interest rate to be lower as they expect the authority to keep the exchange rate target. This leads to the decline in interest rate and domestic currency depreciates.

The increase in the foreign interest rate means lower foreign price. This generates two effects on domestic output and price level (Kim \& Roubini (2000)). The domestic economy tends to follow the step of foreign economy by increasing the domestic interest rate not only foreign country is large and has large effect on the small country but it is also to avoid inflationary effect. This leads to lower money supply and hence lower price. Since price is sticky and adjusts slowly, exchange rate shows a jump appreciation and depreciates back to the new equilibrium level. The depreciation leads to higher price and stimulates higher output or production. On the other hand, higher interest rate tends to dampen the demand and leads to the decline in output (Kim \& Roubini (2000)). In general, the results show that East-Asian countries tend to experience higher output in the pre-crisis period but lower output in the post-crisis period. Nominal depreciation is translated into real exchange rate depreciation in both periods.

A one percent increase in the foreign demand shock, i.e. the increase in the foreign price means the domestic price is relatively lower than the foreign price. Lower domestic price is associated with lower domestic interest rate and domestic currency depreciates. This later leads to higher domestic price and output. On the other hand, under the exchange rate targeting regime, the public anticipate a rise in the future interest rate as they expect the authority will increase the interest rate in the future to maintain the exchange rate target. The expectation on higher interest rate leads to higher price and domestic currency appreciates. The results demonstrate that the intervention of the authorities to control the exchange rate movements which leads to higher price and lower output (in some cases) in both periods. However, nominal appreciation is translated into real depreciation.

Domestic supply shock, for example the increase in productivity leads to higher output or production and lower domestic price. This causes to lower interest rate and domestic currency is expected to depreciate (Goo (2008)). On the other hand, a positive supply shock may also lead to higher interest rate if the increase in the aggregate demand is greater than the increase in aggregate supply. The price tends to be higher and the exchange rate appreciates. In the pre-crisis period with exchange rate targeting regime, domestic economy tends to experience appreciation as the public anticipates the increase in the expected interest. This leads to higher price and exchange rate appreciates. The results are mixed but changes in nominal exchange rate are translated into real depreciation in period II.

Under a negative exchange rate shock, domestic currency is expected to depreciate. This improves the trade balance and induces higher output. On the other hand, depreciation in domestic currency can lead to a fall in output when prices of import and export adjust faster than the increase in the quantity of trade (Goo (2008)). The results show that a positive exchange rate leads to appreciation in domestic currency with higher price. This causes to lower output.

When there is an increase in the demand on domestic goods, domestic price tends to be higher. This induces higher price and production (higher output). Higher demand also leads to higher interest rate and domestic currency appreciates. However, a positive demand shock can also lead to depreciation in domestic currency, especially in the pre-crisis period. This is due to the anticipation of the market participants that revise expectation on the future interest rate. The decline in the expected interest rate is associated with lower price (Goo (2008)). The results here show that domestic demand shock leads to higher price but its effect on output and real exchange rate is not significant. Overall, the responses of domestic variables to shocks are different across countries and between the two sub-periods. However, the economies of Malaysia, Philippines and Thailand tend to experience real depreciation hitting by external shocks in the post-crisis period. This indicates that exchange rate plays a greater role as a shock absorber in these countries aftermath the crisis or after the shift to floating regime. 


\subsection{Correlation of shocks}

The analysis on the correlation of shocks is conducted by constructing the disturbances of shocks in the system equation. The shocks in East-Asian countries are symmetric if the correlation of shocks is positive among countries but they are asymmetric if the correlation is negative or insignificant (Zhang, Sato \& McAleer (2004)). This analysis provides the information on the degree of linkage and similarity in the structural of shocks that faced by the domestic economies of East-Asia.

Table 6 displays the correlations of domestic shocks among East-Asian countries. As observed, the correlations of domestic shocks (domestic supply, real exchange rate and domestic demand shocks) are very low among East-Asian countries. However, the correlation between the real exchange rate and supply shocks show the tendency to increase in the post-crisis period. This may explained by higher regional trade and cooperation among these countries and the move to the same direction in the policy regime, i.e. flexible exchange rate and inflation targeting regimes. As mentioned in Kim, Kose \& Plummer (2000 and 2003), Asian countries exhibit higher intra-Asian trade and closer economic cooperation over time.

\section{The role of exchange rate: a shock absorber or generator?}

The floating exchange rate regime is effective when exchange rate adjusts to external shocks and acts as a shock absorber. The precondition for the exchange rate to act as a shock absorber is changes in nominal exchange rate should be transmitted in real exchange rate changes (Edwards (2006)) (Note 5). However, exchange rate does not always act as a shock absorber. In some circumstances, it even generates larger shocks.

Previous studies show that real exchange rate changes and the effectiveness role of exchange rate as a shock absorber are crucially determined by the source of shocks. Exchange rate has a room for stabilizing and can act as a shock absorber only when an economy experiences asymmetric shocks compare to its trading partner. Therefore, under the existence of asymmetric shocks, the cost of relinquish the exchange rate will be high (Artis \& Ehrmann (2006)).

The analysis on the source and the structure of shocks is conducted by imposing identifications on the structural of shocks in the SVAR model. Shocks are categorized as asymmetric (symmetric) when the domestic and foreign interest rates react differently (similarly) to real shocks (Artis \& Ehrmann (2006)). Exchange rate plays a significant role as a shock absorber in case it reacts strongly to asymmetric shocks. Exchange rate is a shock generator if it reacts mainly to its own shock. However, if the disturbance does not transmit largely to the real economy, exchange rate is not destabilizing (Alexius \& Post (2008) and Artis \& Ehrmann (2006)).

The results of impulse response function (see Table 5 and 7) demonstrate that hitting by external shocks, three economies (except Korea) tend to experience real exchange rate depreciation in the post-crisis period. This implies that exchange rate plays a greater role as shocks absorber in these economies under more flexible regime.

The same evidence also found in the results of forecast error variance decomposition for output and real exchange rate. The FEVD for real exchange rate (see Table 4) shows that real exchange rate reacts strongly to its own shock, indicating that exchange rate is a source of shocks to itself. However, the effect of exchange rate shock has declined in the post-crisis period. At the same time, the effect of foreign demand shock and domestic supply shock on this variable have increased, implying some significant of external and domestic real shocks on real exchange rate. Next, I examine the FEVD for output to see how the disturbance of exchange rate is transmitted to the real economy and if output is determined by the same shocks as in real exchange rate. The FEVD for output shows that output in East-Asian countries are driven mainly by the domestic supply or the real shock. Since both output and real exchange rate variables are affected by different main source of shocks, the results reveal asymmetric shocks i.e. exchange rate can act as a shock absorber. On the other hand, the exchange rate shock has low impact on the movements of output in period I but it is increasing in period II after the move to the flexible regimes (with the exception of Thailand). The results indicate that the disturbance of exchange rate transmits lowly to the real economy in period I, hence exchange rate is not destabilizing. However, the effect is increasing in period II especially in Philippines and exchange rate could be destabilizing in this country. The effect of exchange rate shock on domestic inflation is low in all countries. The results of FEVD are confirmed by the results of impulse response function (see Table 5).

Overall, the results indicate that there is a room for exchange rate to act as a shock absorber given that shocks are asymmetric in this region. Although exchange rate is a source of shocks to itself, it is not harmful as the disturbance of exchange rate shock does not transmit largely to the real economy. However, the effect of exchange rate shock on real economy has increased in the post-crisis period. This change is consistent to the shift in exchange rate regime from the more rigid one to the flexible one and inflation targeting in the post-crisis period. As the real exchange rate reacts stronger to output shock and the domestic economies tend to experience real depreciation caused by the external shocks in period II, the results imply more effective monetary policy and greater role of exchange rate to be a shock absorber under the flexible exchange rate regimes aftermath the crisis.

\section{Conclusion}

This paper conducts a structural VAR analysis to examine the source of business cycle fluctuations in several East-Asian 
countries. The main focus of this analysis is to compare the relative importance of various shocks, the real exchange rate fluctuation and the structure and transmission of shocks across East-Asian countries in the pre- and post-crisis periods/ after the shift of policy regimes. The results provide information for the selection of more appropriate policy regimes and also for the evaluation of monetary policy.

The results indicate that the main sources to the economic fluctuations in East-Asia are domestic shocks, in particular the supply or real shock. External shocks although explain a relatively low fraction in the economic fluctuations of this region, they show a tendency to increase over time. Therefore, the increasingly relative effect of external shocks in East-Asia is one of the aspects that should not be ignored in the monetary policy framework for (the East-Asia) emerging countries.

The results also show that East-Asian countries are subject to asymmetric country specific shocks. The relative importance of shocks differs across countries and the economic variables in these countries react differently to shocks. However, these countries show more similar results in the post-crisis period, indicating more symmetric in the structure of economics in these countries over time. The results are confirmed by the analysis in the correlation of shocks i.e. the correlation in the structure of domestic shocks across countries is higher in the post-crisis period.

Comparing the results of the two sub-periods with the shift of policy regimes from more rigid to flexible one, it is observed that the move to the flexible and inflation targeting regimes results in higher exchange rate volatility. Exchange rate is a source of shocks to itself but it is not destabilizing since its effect on the real economy is very low. At the same time, inflation targeting regime maintains stability in price with lower volatility in inflation. Besides, the domestic economy tends to experience depreciation in real exchange rate with greater rate in response to external shocks in the period aftermath the shift of the policy regimes. Real exchange rate also reacts stronger to output shock in the post-crisis period. These changes imply more effective monetary policy and greater role of exchange rate as a shock absorber in these countries after the shift to the flexible exchange rate and inflation targeting regimes.

Although the analysis on the structure and the source of shocks indicate greater role of exchange rate to act as a shock absorber under flexible regimes in East-Asia, there are some circumstances that the flexible regimes may not work well. For instance, countries that hold large foreign currency denominated liabilities may experience higher debt when the currency depreciates. This may leads to bankruptcies and reduction in the economic growth (Eichengreen \& Hausmann (1999)). Besides, Devereux (2004) also suggests the choice for the peg regime for emerging countries given that international financial market is imperfect. Under the imperfect international financial market, floating regimes do not generate welfare maximization as they do not entail output to react efficiently to external demand shock. Hence, besides the source of shocks, the policy maker should consider other aspects (for example the structure of financial market and exchange rate pass-through) in making the choice of policy regimes.

\section{References}

Alexius, A. \& Post, E. (2008). Exchange rates and asymmetric shocks in small open economies. Empirical Economics 35: 527-541. [Online] Available: http://www.springerlink.com/content/k11085h1370k0540/fulltext.pdf

Aminian, N. (2005). Economic integration and prospects for regional monetary cooperation in East Asia. Structural Change and Economic Dynamics 16: 91-110. [Online] Available: http://www.sciencedirect.com/science/article/B6VFN4CDJN3K-1/2/1e5827428accf6116752edb9607b12ad

Artis, M \& Ehrmann, M. (2006). The exchange rate - a shock absorber or source of shocks? A study of four open economies. Journal of International Money and Finance 25: 874-893. [Online] Available: http://www.sciencedirect.com/ science/article/B6V9S-4KSD567-1/2/559b654ff4840b72077be86a55e42a9b

Bayoumi, T. \& Eichengreen, B. (1994). One money or many? Analyzing the prospects for monetary unification in various parts of the world. Princeton Studies in International Finance, no. 76. Princeton University. [Online] Available: http://www.princeton.edu/ ies/IES_Studies/S76.pdf

Bayoumi, T., Eichengreen, B. \& Mauro, P. (2000). On regional monetary arrangements for ASEAN. Journal of the Japanese and International Economics 14: 121-148.

Bjørnland, H.C. (2004). The role of the exchange rate as a shock absorber in a small open economy. Open Economies Review 15: 23-43. [Online] Available: http://www.sciencedirect.com/science?_ob=ArticleURL\&_udi=B6V9S-4KSD567$1 \&$ _user=2387607\&_rdoc $=1 \&$ _fmt $=$ \&_orig $=$ search\&_sort $=$ d\&view $=$ c\&_acct $=$ C000056415\&_version $=1 \&$ \&urlVersion $=0$ \&_userid=2387607\&md5=b677a1fe952cc0508d7dad9ba2bfc434

Breitung, J. et al. (2004). Structural vector autoregressive modeling and impulse responses. In H.Lütkepohl \& M. Krätzig. Applied time series econometrics. Cambridge University Press. pp. 159-195.

Chow, H.K. \& Kim Y. (2003). A common currency peg in East Asia? Perspectives from Western Europe. Journal of Macroeconomics 25: 331-350. [Online] Available: http://www.sciencedirect.com/science/article/B6X4M-49565731/2/1fd7ada49ef6bff5da9f7c629232e1ab

Desroches, B. (2004). The transmission of world shocks to emerging market countries: an empirical analysis. Bank of 
Canada working paper 2004-44. [Online] Available: http://dsp-psd.pwgsc.gc.ca/Collection/FB3-2-104-44E.pdf

Devereux, M.B. (2004). Monetary policy rules and exchange rate flexibility in a simple dynamic general equilibrium model. Journal of Macroeconomics 26, 287-308.

Drine, I. and Rault, C. (2004). The sources of real exchange fluctuations in developing countries: an econometric investigation. The William Davidson Institute. Working paper no. 653. [Online] Available: http://www.wdi.umich.edu/files/ Publications/WorkingPapers/wp653.pdf

Edwards, S. (2006). The relationship between exchange rates and inflation targeting revisited. NBER working paper series no. 12163. [Online] Available: http://www.nber.org/papers/w12163

Edwards, S. \& Yeyati, E.L. (2005). Flexible exchange rates as shock absorbers. European Economic Review 49, 20792105 .

Edwards, S. \& Yeyati, E.L. (2003). Flexibile exchange rates as shock absorbers. NBER working paper, no. 9867. [Online] Available: http://www.nber.org/papers/w9867.pdf.

Eichengreen, B. \& Bayoumi, T. (1996). Is Asia an optimum currency area? Can it become one? Regional, global and historical perspectives on Asian monetary relations. Center for International and Development Economics Research. University of California, Berkeley. [Online] Available: http://repositories.cdlib.org/cgi/viewcontent.cgi?article=1033\&context= iber/cider.

Eichengreen, B. \& Hausmann, R. (1999). Exchange rates and financial fragility, Proceedings, Federal Reserve Bank of Kansas City, pages 329-368.

Goo, S.W. (2008). The role of exchange rate and inflation targeting policy on economic performances: a SVAR approach. In: Exchange rate and monetary policy: selected comparative experiences during the pre- and post 1997 Asian fiancial crisis. University of Adelaide. Dissertation.

Hoffmaister, A.W. \& Roldós, J. E. (1997). Are business cycles different in Asia and Latin America? IMF working paper WP/97/9. [Online] Available: http://www.imf.org/external/pubs/ft/wp/wp9709.pdf.

Hoffmann, M. (2005). Fixed versus flexible exchange rate: evidence from developing countries. University of Cologne. [Online] Available: http://www.cfr-cologne.de/download/workingpaper/cfr-05-03.pdf.

Kim, S., Kose, M.A. \& Plummer, M.G. (2000). Dynamics of business cycles in Asia: differences and similarities. Brandeis University. Working paper series, vol. 2000-15.

Kim, S., Kose, M.A. \& Plummer, M.G. (2003). Dynamics of business cycles in Asia: differences and similarities. Review of Development Economics, Vol 7, 462-477.

Kim, S. \& Roubini, N. (2000). Exchange rate anomalies in the industrial countries: a solution with structural VAR approach. Journal of Monetary Economics, 45: 561-586. [Online] Available: http://www.sciencedirect.com/science/article/ B6VBW-40964X1-5/2/88ed67564078e5b32540f0ce b4b47271.

Kwack, S.Y. (1999). Capital inflows and monetary policy in Asia before the financial crisis. KIEP working paper, 99-12. Korea Institute for International Economics Policy.

Kwack, S.Y. (2005). Exchange rate and monetary regime options for regional cooperation in East Asia. Journal of Asian Economics, 16: 57-75. [Online] Available: http://www.sciencedirect.com/science?_ob=ArticleURL\&_udi=B6W53-4FN W4P2-1\&_user=2387607\&_rdoc=1\&_fmt=\&_orig=search\&_sort=d\&view=c\&_acct=C000056415\&_version=1\&_ urlVersion=0\&_userid $=2387607 \& \mathrm{md} 5=\mathrm{d} 358 \mathrm{bd} 8 \mathrm{~d} 004 \mathrm{~d} 459 \mathrm{f} 16027 \mathrm{f} 57 \mathrm{edc} 93 \mathrm{f} 5 \mathrm{f}$

Kwan, C.H. (1994). Economic interdependence in the Asia-Pacific region: towards a Yen bloc. Routledge, London.

Ramayandi, A. (2005). ASEAN monetary cooperation: Issues and prospects. Pacific Economic papers, no. 349. Australia-Japan Research Centre. The Australian National University. [Online] Available: www.eaber.org/intranet/ documents/23/1105/Crawford_Ramayandi_2005.pdf

Santiago, Chile. Sun, W. \& An, L. (2008). Asymmetric shocks and exchange rate regimes in East Asia. International Research Journal of Finance and Economics, 22: 38-48. [Online] Available: http://www.eurojournals.com/irjfe_22_03.pdf.

Saucier, P. (2002). The case for an Asian exchange rate mechanism In: Proceedings of the Internatinal Conference Towards regional currency areas.

Thomas, A. (1997). Is the exchange rate as shock absorber? The case of Sweden. International Monetary Fund. IMF working paper, WP/97/176. [Online] Available: http://www.imf.org/external/pubs/ft/wp/wp97176.pdf.

Zhang, Z.Y. et al. (2004). Is a monetary union feasible for East Asia? Applied Economics, 36: 1031-1043.

Zhang, Z.Y., Sato, K. \& McAleer, M. (2004). Asian monetary integration: a structural VAR approach. Mathematics and 
Computers in Simulation, 42: 447-458. [Online] Available: http://www.sciencedirect.com/science?_ob=ArticleURL \&_udi=B6V0T-49J8XPP-1\&_user=2387607\&_rdoc=1\&_fmt=\&_orig=search\&_sort=d\&view=c\&_acct=C000056415 \&_version=1\&_urlVersion=0\&_userid=2387607\&md5=e76ca9bd60c268b237005b1915735834

Notes

Note 1. The estimation applies top-down subset restrictions to improve the outcome, i.e. using an elimination algorithm to conduct a checking procedure from the last regressor to see if exclude this term in the equation improves the criterion value. If yes, the regressor will be eliminate and the process is continue to check the second last regressor and so on.

Note 2. Applying different number of lags in the model does not change the main results. This paper follows previous studies on monthly data to include six lags in the model, for example Kim \& Roubini (2000) and Artis \& Ehrmann (2006).

Note 3. Impulse dummies are assumed for the following cases: Philippines, period II (2000M1 and 2000M10) and Malaysia, period I (1984M3 and 1988M4).

Note 4. However, Thailand experiences a small increase in growth rate.

Note 5. Real depreciation generates relative price effects where domestic price is cheaper than foreign price. This leads to higher demand on domestic goods and improve the balance sheet of domestic country. 
Table 1. Monetary Policy Framework

\begin{tabular}{|c|c|c|}
\hline No & Countries & Monetary Policy Framework \\
\hline 1 & Korea & 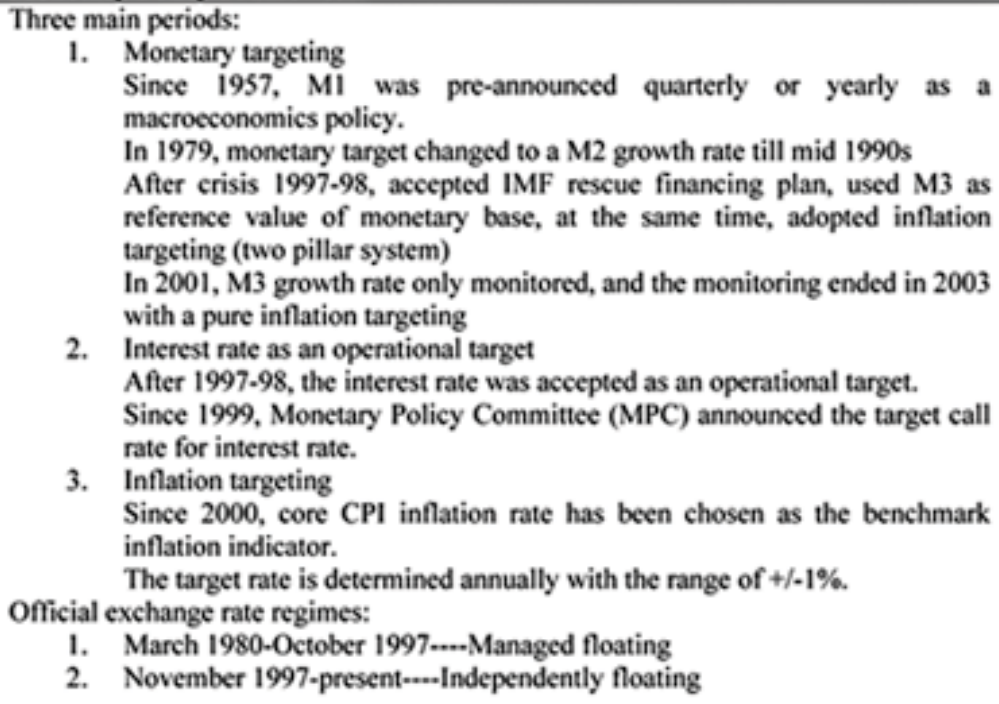 \\
\hline 2 & Malaysia & $\begin{array}{l}\text { Official exchange rate regimes: } \\
\text { 1. January 1986-February 1990-...-Limited flexibility } \\
\text { 2. March 1990-November 1992-..-Fixed } \\
\text { 3. December 1992-September 1998-..-Managed floating } \\
\text { 4. September 1998-July 2005-...-Pegged arrangement } \\
\text { 5. July 2005-present -..-Managed floating } \\
\end{array}$ \\
\hline 3 & Philippines & $\begin{array}{l}\text { Two periods: } \\
\text { 1. Monetary targeting } \\
\text { In the past, monetary policy framework based on base or reserve money } \\
\text { programming. } \\
\text { 2. Inflation targeting ( } 2002 \text { onwards) } \\
\text { Inflation targeting policy adopted formally in January } 2000 \text { and the } \\
\text { implementation started in January } 2002 \text {. } \\
\text { CPI or headline inflation is used as its monetary policy target and } \\
\text { overnight repurchase rate and reverse repurchase rate are used as the main } \\
\text { instrument of monetary policy. } \\
\text { Official exchange rate regimes: } \\
\text { 1. January 1988-present-..-Independently floating }\end{array}$ \\
\hline 4 & Thailand & $\begin{array}{l}\text { Three main periods: } \\
\text { 1. Pegged exchange rate regime ( } 2^{\text {nd }} \text { World War-June 1997) } \\
\text { The value of Baht was pegged to a major currency/gold or to a basket of } \\
\text { currencies } \\
\text { 2. Monetary targeting regime (July 1997-May 2000) } \\
\text { Beginning the periods of floating exchange rate. } \\
\text { Received assistance from IMF, targeted at domestic money supply. } \\
\text { Set daily and quarterly monetary base targets. } \\
\text { 3. Inflation targeting regime (May 2000-present) } \\
\text { Inflation targeting is more effective as the relationship between money } \\
\text { supply and output growth was becoming less stable after financial crisis. } \\
\text { Official exchange rate regimes: } \\
\text { 1. January 1970-June 1997.-..-fixed } \\
\text { 2. July 1997-present-..-Independently floating }\end{array}$ \\
\hline
\end{tabular}


Table 2. Augmented Dicky-Fuller (ADF) Unit-root test

\begin{tabular}{|c|c|c|c|c|c|c|c|c|c|c|}
\hline Variablet & \multicolumn{2}{|c|}{ Koreas } & \multicolumn{2}{|c|}{ Malaysia } & \multicolumn{2}{|c|}{ Philippines } & \multicolumn{2}{|c|}{ Thalaeds } & \multicolumn{2}{|c|}{ ES } \\
\hline$v$ & Period IV & Period II & Period It & Period:II & Period-Io & Period II & Period I $v$ & Period II & Perisd Is & Period II \\
\hline $\begin{array}{l}y^{*}+ \\
\Delta y^{*} \cdot\end{array}$ & & & & & & & & & 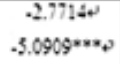 & $\begin{array}{c}-1.4200 * \\
-10.4592=\cdots\end{array}$ \\
\hline $\begin{array}{l}j \% \\
\Delta * v\end{array}$ & & & & & & & & & $\begin{array}{c}-2.0925 \\
-3.6192 * \cdots\end{array}$ & $\begin{array}{c}.2 .12864 \\
-2.9074 * * 0\end{array}$ \\
\hline $\begin{array}{l}p^{*} * \\
\Delta p^{*}=\end{array}$ & & & & & & & & & $\begin{array}{c}-1.89344 \\
-6.7386 * \cdots\end{array}$ & $\begin{array}{c}-1.14194 \\
-\$ .6924 \cdots \cdots\end{array}$ \\
\hline $\begin{array}{l}y+ \\
\Delta y, 0\end{array}$ & $\begin{array}{c}-2.1331+ \\
-21.8048 \cdots \cdots\end{array}$ & $\begin{array}{c}-3.7930^{* *} \\
-11.2026 * \cdots\end{array}$ & $\begin{array}{c}-2.3859 \\
-21.8043 * \cdots\end{array}$ & $\begin{array}{c}-3.1423^{*}+ \\
-6.3390 * \cdots+\end{array}$ & $\begin{array}{c}-2.0539+ \\
-9.5618 \cdots \cdots\end{array}$ & $\begin{array}{c}-2.1313 * \\
-8.3034 * \cdots\end{array}$ & $\begin{array}{c}-1.206 \$+ \\
-12.9193 \cdots \cdots\end{array}$ & $\begin{array}{c}-2.3500+ \\
-6.8498 \cdots\end{array}$ & & \\
\hline $\begin{array}{c}r, v \\
\Delta r \theta\end{array}$ & $\begin{array}{c}-0.5716 \% \\
.9 .7418 \cdots * *\end{array}$ & $\begin{array}{c}-1.7960 * \\
-9.2745 * \cdots *\end{array}$ & $\begin{array}{c}-0.8499 * \\
-12.7499 * \cdots\end{array}$ & $\begin{array}{c}-1.9419+ \\
-9.4366 * \cdots * v\end{array}$ & $\begin{array}{c}0.1314 \alpha \\
-13.7909 * \cdots\end{array}$ & $\begin{array}{c}-1.9146 * \\
-9.8324 * \cdots * 0\end{array}$ & $\begin{array}{c}0.0096 * \\
-8.8962 * \cdots,\end{array}$ & $\begin{array}{c}-1.9675+0 \\
.9 .7887 \cdots \cdots *\end{array}$ & & \\
\hline $\begin{array}{l}p, \\
\Delta p\end{array}$ & $\begin{array}{l}-1.1804+ \\
.9 .3978+\end{array}$ & $\begin{array}{c}2.6633 v \\
.9 .3256 * * * 0\end{array}$ & $\begin{array}{c}-1.3682 \% \\
-11.4576 * * * *\end{array}$ & $\begin{array}{c}-1.1688 * \\
-11.5337 * * * 0\end{array}$ & $\begin{array}{c}-2.25600 \\
.6 .9011 \cdots * \omega\end{array}$ & $\begin{array}{c}-2.0930 * \\
-4.9143 * * * 0\end{array}$ & $\begin{array}{c}-1.9543 * \\
9.3499 * * * 0\end{array}$ & $\begin{array}{c}0.9396 \% \\
.6 .3199 * * * 0\end{array}$ & & \\
\hline
\end{tabular}

Notes: All the series are in $\log$ form except the series for interest rate. The series for the level of $y^{*}, y, p_{t}$ and $p_{t}$ are assumed to have constant term, trend and seasonal dummies while the differenced of these variables are assumed to exhibit constant and seasonal dummies. The other variables are assumed to have constant term. The selection on the number of lags for each series is based on the number suggested by Akaike Info Criterion, Final Prediction Error and Schwarz Criterion.

$\Delta$ denotes the first differenced operator. $* * *$ denotes the significant statistic at $1 \%$ level; $* *$ the significant statistic at $5 \%$ level and $*$ the significant statistic at $10 \%$ level.

Table 3. Descriptive statistics

\begin{tabular}{|c|c|c|c|c|c|c|c|c|}
\hline \multirow{2}{*}{$\frac{\theta}{9}$} & \multicolumn{2}{|c|}{ Korea } & \multicolumn{2}{|c|}{ Malaysias } & \multicolumn{2}{|c|}{ Philippines } & \multicolumn{2}{|c|}{ Thailand } \\
\hline & Period I & Period-IIs & Period.I & Period.II & Period I & PeriodII & Period I & PeriodII \\
\hline$\frac{\Delta p_{1}^{*}}{\operatorname{mean}}$ & $\begin{array}{c}0.0044 \\
0.0053\end{array}$ & $\begin{array}{c}\vdots \\
0.0025 \\
0.0041\end{array}$ & $\begin{array}{c}\vdots \\
0.0027 \\
0.00400\end{array}$ & $\begin{array}{c}0.0017 \\
0.0027\end{array}$ & $\begin{array}{c}\dot{4} \\
0.0093 \\
0.0123\end{array}$ & $\begin{array}{c}0.00390 \\
0.00580\end{array}$ & $\begin{array}{c}\vdots \\
0.0036 \\
0.0051\end{array}$ & $\begin{array}{c}4 \\
0.0022 \\
0.0042 \%\end{array}$ \\
\hline$\frac{\Delta y_{2} *}{\operatorname{mean}}$ & $\begin{array}{c} \\
0.0082 \\
0.0348\end{array}$ & $\begin{array}{c}* \\
0.0069 \\
0.0397\end{array}$ & $\begin{array}{c}\dot{v} \\
0.0079 \\
0.06300\end{array}$ & $\begin{array}{c} \\
0.0054 \\
0.0367\end{array}$ & $\begin{array}{c} \\
0.0105 \\
0.05010\end{array}$ & $\begin{array}{c}* \\
0.0060 \\
0.05100\end{array}$ & $\begin{array}{c} \\
0.0071 \\
0.0381\end{array}$ & $\begin{array}{c}* \\
+ \\
0.0079 \\
0.0321\end{array}$ \\
\hline$\frac{\Delta r_{z}+}{\operatorname{mean}}$ & $\begin{array}{c}\vdots \\
0.0014 \\
0.0103\end{array}$ & $\begin{array}{c}4 \\
0.0002 \\
0.0240\end{array}$ & $\begin{array}{c}\dot{\checkmark} \\
0.0005 \\
0.0127\end{array}$ & $\begin{array}{c}0 \\
0.00060 \\
0.0120\end{array}$ & $\begin{array}{c}4 \\
0.0014 \\
0.0331\end{array}$ & $\begin{array}{c}\dot{2} \\
0.0068 \\
0.0232 v\end{array}$ & $\begin{array}{c}\vdots \\
0.0010 \\
0.0166\end{array}$ & $\begin{array}{c}* \\
0.0004 \% \\
0.0206 \%\end{array}$ \\
\hline
\end{tabular}

The variables are in first differenced log form. The data are in monthly and spanning from 1980's-1997M6 (period I) and 1999M1-2008M4 (period II). A one percentage is equivalent to 0.01 . 


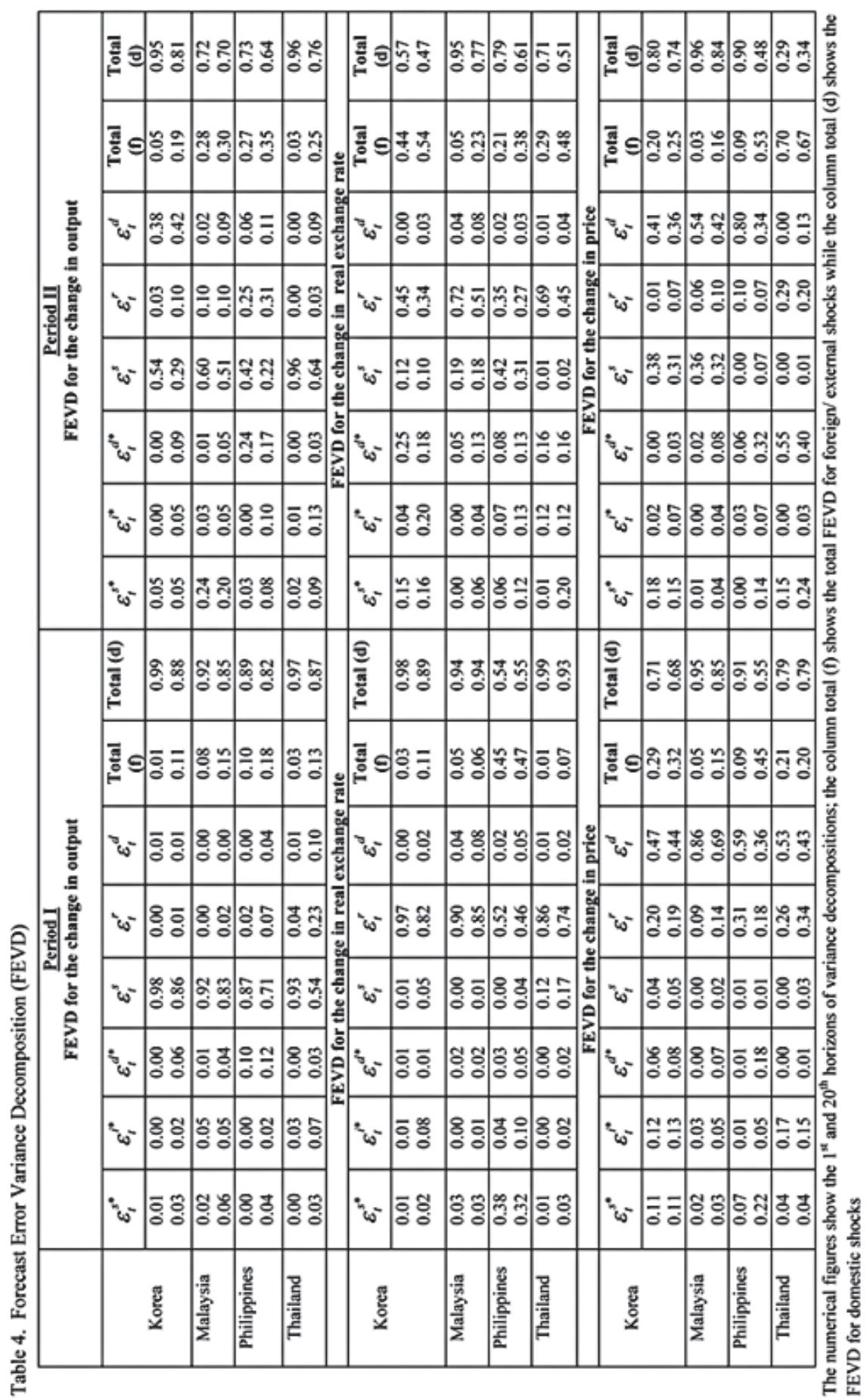


Table 5. The size of shocks under Impulse Response Functions (IRF)

\begin{tabular}{|c|c|c|c|c|c|c|c|c|c|c|c|c|}
\hline \multirow{3}{*}{ Korea } & \multicolumn{6}{|c|}{$\frac{\text { Period I }}{\text { Output growth }}$} & \multicolumn{6}{|c|}{$\begin{array}{c}\text { Period II } \\
\text { Output growth }\end{array}$} \\
\hline & $\varepsilon_{t}^{s^{*}}$ & $\varepsilon_{t}^{i^{*}}$ & $\varepsilon_{t}^{d^{*}}$ & $\varepsilon_{t}^{s}$ & $\varepsilon_{t}^{r}$ & $\varepsilon_{t}^{d}$ & $\varepsilon_{t}^{s^{*}}$ & $\varepsilon_{t}^{i^{*}}$ & $\varepsilon_{t}^{d^{*}}$ & $\varepsilon_{t}^{s}$ & $\varepsilon_{t}^{r}$ & $\varepsilon_{t}^{d}$ \\
\hline & $\begin{array}{c}-16 \\
-9 \\
1 \\
6\end{array}$ & $\begin{array}{l}40 \\
40 \\
44 \\
39\end{array}$ & $\begin{array}{l}-28 \\
-15 \\
-28 \\
-27\end{array}$ & $\begin{array}{l}143 \\
164 \\
169 \\
166\end{array}$ & $\begin{array}{c}10 \\
6 \\
2 \\
1 \\
\end{array}$ & $\begin{array}{c}30 \\
0 \\
3 \\
-2\end{array}$ & $\begin{array}{c}45 \\
125 \\
98 \\
82\end{array}$ & $\begin{array}{c}8 \\
-79 \\
-65 \\
-90\end{array}$ & $\begin{array}{l}16 \\
47 \\
20 \\
24\end{array}$ & $\begin{array}{l}31 \\
98 \\
85 \\
99\end{array}$ & $\begin{array}{c}44 \\
-11 \\
-5 \\
11 \\
\end{array}$ & $\begin{array}{c}-9 \\
9 \\
-16 \\
-2\end{array}$ \\
\hline Malaysia & $\begin{array}{c}-3 \\
141 \\
164 \\
170\end{array}$ & $\begin{array}{l}55 \\
64 \\
61 \\
63 \\
\end{array}$ & $\begin{array}{c}59 \\
22 \\
0 \\
-11\end{array}$ & $\begin{array}{l}243 \\
267 \\
277 \\
276 \\
\end{array}$ & $\begin{array}{c}-47 \\
28 \\
9 \\
2\end{array}$ & $\begin{array}{l}7 \\
5 \\
5 \\
2\end{array}$ & $\begin{array}{l}110 \\
221 \\
184 \\
166\end{array}$ & $\begin{array}{c}30 \\
21 \\
-12 \\
-39\end{array}$ & $\begin{array}{r}27 \\
14 \\
-22 \\
-12\end{array}$ & $\begin{array}{c}15 \\
89 \\
108 \\
106\end{array}$ & $\begin{array}{c}7 \\
0 \\
10 \\
3 \\
\end{array}$ & $\begin{array}{c}-10 \\
-30 \\
6 \\
4 \\
\end{array}$ \\
\hline Philippines & $\begin{array}{l}-42 \\
-23 \\
-10 \\
-14 \\
\end{array}$ & $\begin{array}{c}-21 \\
43 \\
63 \\
64 \\
\end{array}$ & $\begin{array}{l}79 \\
55 \\
64 \\
72\end{array}$ & $\begin{array}{l}196 \\
147 \\
167 \\
164 \\
\end{array}$ & $\begin{array}{c}-23 \\
-13 \\
0 \\
0 \\
\end{array}$ & $\begin{array}{c}-3 \\
-8 \\
-8 \\
0 \\
\end{array}$ & $\begin{array}{c}-16 \\
4 \\
23 \\
36 \\
\end{array}$ & $\begin{array}{l}37 \\
-2 \\
39 \\
31 \\
\end{array}$ & $\begin{array}{c}113 \\
127 \\
94 \\
84 \\
\end{array}$ & $\begin{array}{c}82 \\
139 \\
112 \\
106 \\
\end{array}$ & $\begin{array}{r}-43 \\
-53 \\
17 \\
-5 \\
\end{array}$ & $\begin{array}{c}-22 \\
22 \\
-13 \\
3 \\
\end{array}$ \\
\hline Thailand & $\begin{array}{l}-10 \\
-40 \\
-71 \\
-87\end{array}$ & $\begin{array}{c}-2 \\
0 \\
7 \\
-1\end{array}$ & $\begin{array}{l}15 \\
27 \\
56 \\
62\end{array}$ & $\begin{array}{l}240 \\
158 \\
188 \\
188\end{array}$ & $\begin{array}{c}38 \\
-54 \\
-17 \\
-6\end{array}$ & $\begin{array}{c}44 \\
-4 \\
3 \\
-1\end{array}$ & $\begin{array}{c}30 \\
64 \\
110 \\
71\end{array}$ & $\begin{array}{l}-7 \\
-7 \\
-24 \\
-23\end{array}$ & $\begin{array}{c}15 \\
-18 \\
-33 \\
-15\end{array}$ & $\begin{array}{l}50 \\
58 \\
69 \\
55\end{array}$ & $\begin{array}{c}10 \\
0 \\
2 \\
-3\end{array}$ & $\begin{array}{c}13 \\
2 \\
-9 \\
-7\end{array}$ \\
\hline & \multicolumn{6}{|c|}{ The change in real exchange rate } & \multicolumn{6}{|c|}{ The change in real exchange rate } \\
\hline Korea & $\varepsilon_{t}^{s^{*}}$ & $\varepsilon_{t}^{i^{*}}$ & $\varepsilon_{t}^{d^{*}}$ & $\varepsilon_{t}^{s}$ & $\varepsilon_{t}^{r}$ & $\varepsilon_{t}^{d}$ & $\varepsilon_{t}^{s^{*}}$ & $\varepsilon_{t}^{i^{*}}$ & $\varepsilon_{t}^{d^{*}}$ & $\varepsilon_{t}^{s}$ & $\varepsilon_{t}^{r}$ & $\varepsilon_{t}^{d}$ \\
\hline & $\begin{array}{l}-9 \\
-23 \\
-15 \\
-14\end{array}$ & $\begin{array}{l}12 \\
58 \\
68 \\
79\end{array}$ & $\begin{array}{l}-9 \\
-5 \\
-2 \\
-5\end{array}$ & $\begin{array}{c}5 \\
36 \\
42 \\
46\end{array}$ & $\begin{array}{l}106 \\
119 \\
129 \\
127\end{array}$ & $\begin{array}{c}9 \\
20 \\
3 \\
2\end{array}$ & $\begin{array}{c}59 \\
153 \\
127 \\
72\end{array}$ & $\begin{array}{c}46 \\
182 \\
188 \\
142\end{array}$ & $\begin{array}{l}-94 \\
-44 \\
-43 \\
-40\end{array}$ & $\begin{array}{l}-38 \\
-44 \\
-34 \\
-28\end{array}$ & $\begin{array}{l}135 \\
137 \\
172 \\
186\end{array}$ & $\begin{array}{c}8 \\
2 \\
0 \\
-9\end{array}$ \\
\hline Malaysia & $\begin{array}{c}21 \\
9 \\
9 \\
10 \\
\end{array}$ & $\begin{array}{c}-9 \\
-13 \\
-13 \\
-14 \\
\end{array}$ & $\begin{array}{l}-19 \\
-8 \\
-4 \\
-4\end{array}$ & $\begin{array}{c}-4 \\
3 \\
-1 \\
0 \\
\end{array}$ & $\begin{array}{l}116 \\
134 \\
132 \\
133\end{array}$ & $\begin{array}{c}-10 \\
1 \\
-1 \\
0\end{array}$ & $\begin{array}{l}-19 \\
-51 \\
-72 \\
-71 \\
\end{array}$ & $\begin{array}{c}-14 \\
-27 \\
-18 \\
-8 \\
\end{array}$ & $\begin{array}{l}-53 \\
-62 \\
-47 \\
-43 \\
\end{array}$ & $\begin{array}{l}-46 \\
-54 \\
-70 \\
-73\end{array}$ & $\begin{array}{l}93 \\
55 \\
71 \\
74\end{array}$ & $\begin{array}{c}-18 \\
-2 \\
-2 \\
0\end{array}$ \\
\hline Philippines & $\begin{array}{l}127 \\
144 \\
149 \\
148 \\
\end{array}$ & $\begin{array}{l}-14 \\
-25 \\
-27 \\
-28 \\
\end{array}$ & $\begin{array}{l}-27 \\
-7 \\
-5 \\
-3\end{array}$ & $\begin{array}{c}-10 \\
19 \\
14 \\
16 \\
\end{array}$ & $\begin{array}{l}123 \\
173 \\
167 \\
168 \\
\end{array}$ & $\begin{array}{c}-10 \\
2 \\
-1 \\
0\end{array}$ & $\begin{array}{c}42 \\
-47 \\
-79 \\
-95\end{array}$ & $\begin{array}{c}-46 \\
-124 \\
-140 \\
-153\end{array}$ & $\begin{array}{l}-44 \\
45 \\
74 \\
95 \\
\end{array}$ & $\begin{array}{l}-109 \\
-106 \\
-116 \\
-115 \\
\end{array}$ & $\begin{array}{c}101 \\
96 \\
115 \\
117\end{array}$ & $\begin{array}{l}-15 \\
-9 \\
-3 \\
-2\end{array}$ \\
\hline Thailand & $\begin{array}{c}-5 \\
5 \\
-1 \\
0\end{array}$ & $\begin{array}{c}-6 \\
-17 \\
-16 \\
-14\end{array}$ & $\begin{array}{c}-3 \\
-11 \\
-5 \\
-7\end{array}$ & $\begin{array}{c}17 \\
-22 \\
-9 \\
-11\end{array}$ & $\begin{array}{l}76 \\
44 \\
50 \\
51\end{array}$ & $\begin{array}{c}5 \\
-6 \\
2 \\
1 \\
\end{array}$ & $\begin{array}{c}-20 \\
-22 \\
-133 \\
-160\end{array}$ & $\begin{array}{c}-57 \\
-76 \\
-88 \\
-104\end{array}$ & $\begin{array}{l}-65 \\
-62 \\
-35 \\
-38 \\
\end{array}$ & $\begin{array}{c}13 \\
-4 \\
5 \\
2 \\
\end{array}$ & $\begin{array}{l}136 \\
140 \\
137 \\
147\end{array}$ & $\begin{array}{c}-17 \\
-22 \\
-5 \\
4\end{array}$ \\
\hline & \multicolumn{6}{|c|}{ The change in price/ inflation } & \multicolumn{6}{|c|}{ The change in price/ inflation } \\
\hline Korea & $\varepsilon_{t}^{s^{*}}$ & $\varepsilon_{t}^{i^{*}}$ & $\varepsilon_{t}^{d^{*}}$ & $\varepsilon_{t}^{s}$ & $\varepsilon_{t}^{r}$ & $\varepsilon_{t}^{d}$ & $\varepsilon_{t}^{s^{*}}$ & $\varepsilon_{t}^{i^{*}}$ & $\varepsilon_{t}^{d^{*}}$ & $\varepsilon_{t}^{s}$ & $\varepsilon_{t}^{r}$ & $\varepsilon_{t}^{d}$ \\
\hline & $\begin{array}{l}-15 \\
-22 \\
-25 \\
-26\end{array}$ & $\begin{array}{l}-16 \\
-18 \\
-22 \\
-22 \\
\end{array}$ & $\begin{array}{l}11 \\
21 \\
24 \\
26\end{array}$ & $\begin{array}{l}-9 \\
-7 \\
-7 \\
-7\end{array}$ & $\begin{array}{l}20 \\
18 \\
20 \\
21 \\
\end{array}$ & $\begin{array}{l}31 \\
34 \\
35 \\
35 \\
\end{array}$ & $\begin{array}{c}-8 \\
-14 \\
-15 \\
-13\end{array}$ & $\begin{array}{c}-2 \\
-9 \\
-10 \\
-9\end{array}$ & $\begin{array}{l}5 \\
4 \\
4 \\
2 \\
\end{array}$ & $\begin{array}{c}-14 \\
-8 \\
-11 \\
-10 \\
\end{array}$ & $\begin{array}{l}-3 \\
-2 \\
-4 \\
-4\end{array}$ & $\begin{array}{c}17 \\
9 \\
12 \\
11\end{array}$ \\
\hline Malaysia & $\begin{array}{c}2 \\
-1 \\
0 \\
1 \\
\end{array}$ & $\begin{array}{c}5 \\
-1 \\
-1 \\
-1 \\
\end{array}$ & $\begin{array}{c}7 \\
18 \\
22 \\
22 \\
\end{array}$ & $\begin{array}{c}-2 \\
4 \\
3 \\
3 \\
\end{array}$ & $\begin{array}{l}10 \\
20 \\
19 \\
20 \\
\end{array}$ & $\begin{array}{l}30 \\
37 \\
38 \\
39 \\
\end{array}$ & $\begin{array}{l}0 \\
4 \\
4 \\
4 \\
\end{array}$ & $\begin{array}{c}5 \\
8 \\
10 \\
10 \\
\end{array}$ & $\begin{array}{c}3 \\
10 \\
11 \\
11 \\
\end{array}$ & $\begin{array}{l}-10 \\
-14 \\
-14 \\
-13 \\
\end{array}$ & $\begin{array}{l}4 \\
7 \\
8 \\
8 \\
\end{array}$ & $\begin{array}{l}12 \\
13 \\
13 \\
14 \\
\end{array}$ \\
\hline Philippines & $\begin{array}{c}-25 \\
-69 \\
-90 \\
-106\end{array}$ & $\begin{array}{c}1 \\
24 \\
34 \\
39 \\
\end{array}$ & $\begin{array}{l}13 \\
60 \\
82 \\
99 \\
\end{array}$ & $\begin{array}{c}1 \\
12 \\
7 \\
9 \\
\end{array}$ & $\begin{array}{l}27 \\
21 \\
20 \\
19 \\
\end{array}$ & $\begin{array}{l}46 \\
46 \\
58 \\
63\end{array}$ & $\begin{array}{c}0 \\
-24 \\
-23 \\
-19\end{array}$ & $\begin{array}{c}-5 \\
-14 \\
-19 \\
-19\end{array}$ & $\begin{array}{l}16 \\
44 \\
50 \\
52\end{array}$ & $\begin{array}{c}7 \\
11 \\
9 \\
7\end{array}$ & $\begin{array}{l}3 \\
3 \\
6 \\
7\end{array}$ & $\begin{array}{l}22 \\
25 \\
26 \\
27\end{array}$ \\
\hline Thailand & $\begin{array}{l}-7 \\
-9 \\
-5 \\
-3\end{array}$ & $\begin{array}{c}-13 \\
-8 \\
0 \\
2\end{array}$ & $\begin{array}{l}1 \\
3 \\
2 \\
1\end{array}$ & $\begin{array}{c}0 \\
-2 \\
0 \\
-2\end{array}$ & $\begin{array}{c}16 \\
6 \\
8 \\
8\end{array}$ & $\begin{array}{l}23 \\
25 \\
24 \\
23\end{array}$ & $\begin{array}{l}-15 \\
-21 \\
-4 \\
-3\end{array}$ & $\begin{array}{c}4 \\
-3 \\
-4 \\
-1\end{array}$ & $\begin{array}{l}27 \\
40 \\
28 \\
27\end{array}$ & $\begin{array}{c}0 \\
-3 \\
-3 \\
-3\end{array}$ & $\begin{array}{l}19 \\
15 \\
19 \\
17\end{array}$ & $\begin{array}{l}11 \\
27 \\
24 \\
20\end{array}$ \\
\hline
\end{tabular}

The numerical figures show the $1^{\text {st }}, 6^{\text {th }}, 12^{\text {th }}$ and $18^{\text {th }}$ month responses of domestic variables to the $1 \%$ or 0.01 increase in the standard deviation of various orthogonalized shocks. The numerical responses are indicated in $\left(x 10^{-4}\right)$. 
Table 6. Correlations of domestic shocks across East-Asian countries

\begin{tabular}{|c|c|c|c|c|c|c|c|c|c|}
\hline & $\frac{\text { Period I }}{\text { Korea }}$ & \multicolumn{3}{|c|}{ Period I } & & \multicolumn{3}{|l|}{ Period II } & Thai \\
\hline & \multicolumn{5}{|c|}{ Domestic supply shock } & \multicolumn{4}{|c|}{ Domestic supply shock } \\
\hline Korea & 1.0000 & & & & Korea & 1.0000 & & & \\
\hline Malaysia & -0.0542 & 1.0000 & & & Malaysia & 0.0938 & 1.0000 & & \\
\hline Philippines & 0.1595 & -0.0805 & 1.0000 & & Philippines & -0.0854 & 0.1357 & 1.0000 & \\
\hline \multirow[t]{2}{*}{ Thailand } & 0.2506 & 0.0027 & -0.0218 & 1.0000 & Thailand & 0.2924 & 0.3250 & 0.2586 & 1.0000 \\
\hline & \multicolumn{4}{|c|}{ Exchange rate shock } & & \multicolumn{4}{|c|}{ Exchange rate shock } \\
\hline Korea & 1.0000 & & & & Korea & 1.0000 & & & \\
\hline Malaysia & 0.0209 & 1.0000 & & & Malaysia & 0.4594 & 1.0000 & & \\
\hline Philippines & 0.1521 & 0.1180 & 1.0000 & & Philippines & 0.3720 & 0.4828 & 1.0000 & \\
\hline \multirow[t]{2}{*}{ Thailand } & 0.2093 & 0.2849 & 0.0864 & 1.0000 & Thailand & 0.5142 & 0.3329 & 0.4046 & 1.0000 \\
\hline & \multicolumn{4}{|c|}{ Domestic demand shock } & & \multicolumn{4}{|c|}{ Domestic demand shock } \\
\hline Korea & 1.0000 & & & & Korea & 1.0000 & & & \\
\hline Malaysia & 0.0606 & 1.0000 & & & Malaysia & -0.2653 & 1.0000 & & \\
\hline Philippines & 0.0968 & 0.0965 & 1.0000 & & Philippines & 0.0807 & -0.1673 & 1.0000 & \\
\hline Thailand & 0.0269 & 0.0274 & 0.1691 & 1.0000 & Thailand & 0.0672 & 0.0018 & 0.1895 & 1.0000 \\
\hline
\end{tabular}




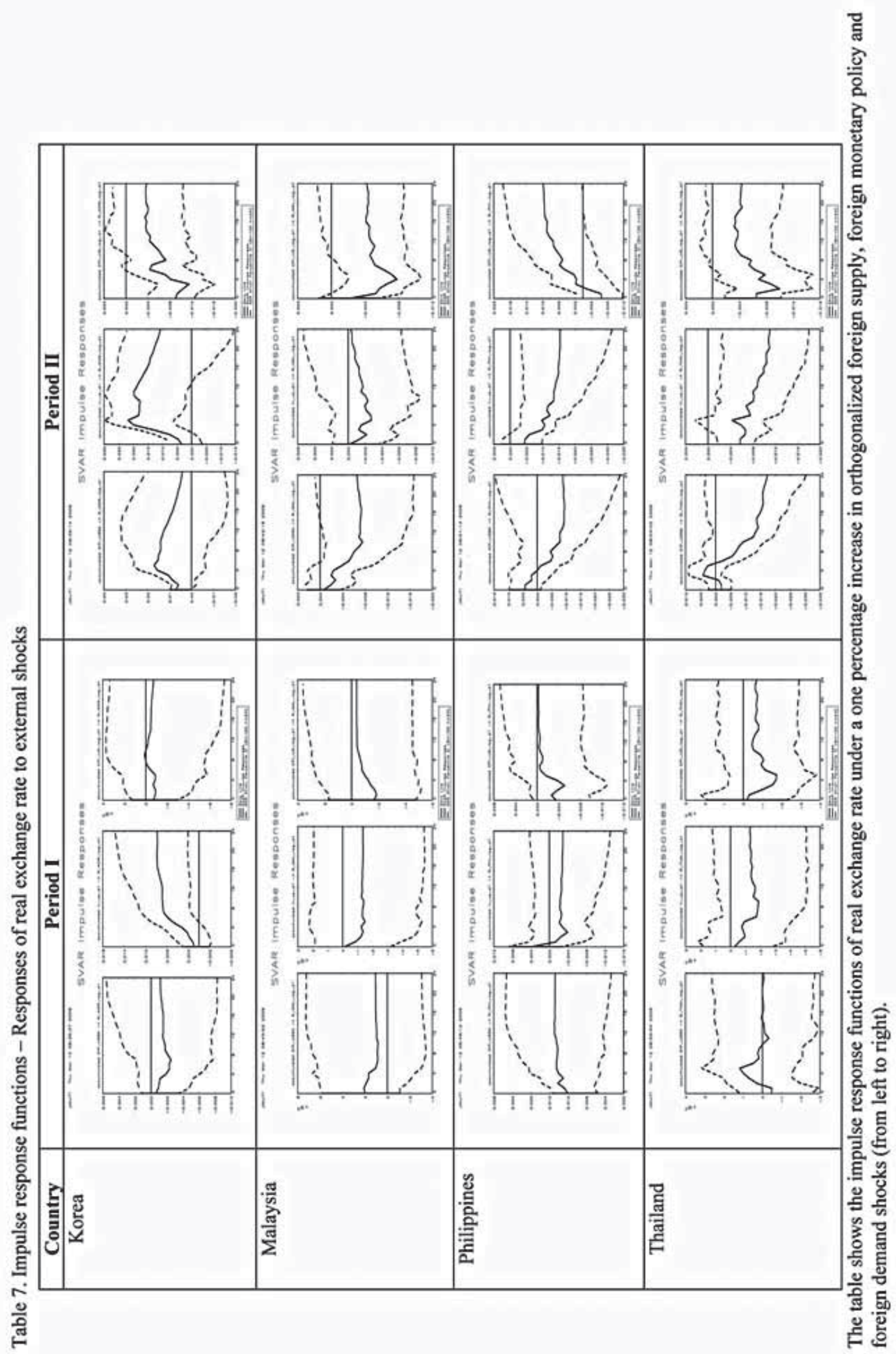

